to 101.4 in the afternoon, when the nurse gave her one tea. spoonful of carbolic acid (red) in one-fourth glass of water.

In three minutes she was unconscious, her lips and face livid, and muscles rigid.

The nurse gave mustard and warm water without effect, then she was given magnesia, lime-water, sweet oil and raw eggs. In fifteen minutes she was profoundly comatose and would have died of heart failure, but was given, hypodermically, morphin and strychnia, and death took place from the lungs. She was dead in less than forty minutes.

W. L. REAGan, M.D.

\section{A Query on Serum Treatment.}

J ACkson, Tenn., Sept. 9, 1897.

To the Editor:-Since it appears that the serum of the blood taken from those who have typhoid fever will destroy the typhoid bacillus, is it not reasonable to suppose that serum taken from those who have just recovered from the disease and inserted into the blood or tissues of those who have it, may prove a remedy for the disease?

Or, for fear of contamination from the blood of those who had it, may not the typhoid bacillus be injected into the horse or cow and the serum taken from those animals and injected into the blood or tissues of typhoid patients prove to be an antitoxin to the disease?

J. A. Crook, M.D.

\section{SOCIETY NEWS.}

The American Academy of Railway Surgeons elected the following officers; President, Dr. R. Harvey Reed, Columbus, Ohio; first vice president, Dr. W. J. Mayo, Rochester, Minn. ; second vice president, Dr. Arthur D. Bevan, Chicago ; secretary, Dr. C. D. Bryant, Omaha. Place of meeting, Chicago, 1898.

The International Congress of Pharmacy, Brussels, August 14 to 19 , recommended the institution of a superior council of legal chemistry; also that the usual denomination given to a chemic product cease to be a trade mark or private property after it has fallen into the public domain (referring to products with well-defined formulæ, antipyrin for example). An international committee was appointed to prepare a codex of methods of analyzing for the titration of drugs and Galenic preparations containing definite principles. Professor Remington of Philadelphia delivered an address on "Revision of the Pharmacopeia," with an appeal for concerted action on the part of phy. sicians and druggists, the former agreeing not to prescribe secret formula remedies and the latter agreeing not to manufacture them. Denayer concluded his report on "Organ Extracts," by urging the importance of absolute sterility in the liquid form and absolute freedom from moisture in the powder, tablet, etc., form, kept preferably in dessicators $a$ la chaux (lime). All the European countries, the United States and Mexico were well represented. The next congress will convene in Paris in 1900.

Newport (R. I.) Medical Society.-Newport, R. I., Sept. 11, 1897. Dear Doctor :-As chairman of a committee of the Newport Medical Society I am directed to call the attention of all Medical Societies and Journals to the following letter :

At a regular meeting of the Newport Medical Society, held Wednesday, May 19, 1897, the following resolutions wer unanimously passed :

Resolved, That it is the opinion of this Society that Congress should change the existing laws regarding the employment of physicians on steamships and other vessels and, with a view to the attainment of that end, the Society deems it advisable that the words "other than ferry boats" be inserted between the words "vessels" and "carrying," which are on the eighth line on the forty-ninth page in Section 5, Chapter 6, Title fortyeight of the "Laws Governing the Steamboat Inspection Ser vice, Revised Statutes of the United States as amended by various Acts of Congress, printed 1896." Also that the word "immigrant" on the ninth line of the same page be erased.
Also that the words "or passengers or other than cabin passengers"' on the ninth and tenth lines of the same page (fortyninth) be erased and the words "lying between one inspector's district and another or going foreign" be inserted instead. Also that the word "fifty" be erased and the word "thirty.five" be substituted for it on the tenth line of the forty-ninth page. Also that on the twelfth line between the words "articles" and "and" should be inserted the words "and not required to do other duties that those usually required of a ship's surgeon on government vessels." Also that after the word "dollars" on the twenty second line on the forty-ninth page should be inserted the words "for each trip or voyage."

Resolved, That the President and Secretary of the Newport Medical Society forward to the President (Dr. Nicholas Senn) of the American Medical Association a copy of these resolutions, and urge in their communication to him the expediency of urgent action on the part of the delegates to the AMERICAN Medical Association, and also that each delegate shall use all influence with his individual Congressman to attain this very desirable result.

A copy of these resolutions was forwarded to the President of the American Medical Association, with two copies of the "Laws governing the steamboat inspection service," one for the President and one for the Secretary, Dr. W. B. A tkinson, both marked. Our delegate, Dr. Mary E. Baldwin, delivered the resolutions to the Secretary, who informs us that, owing to great pressure of business, they were not brought before the Association by him, expecting that our delegate would present them; and as our delegate expected that they would be presented by the Secretary they were, unfortunately, not presented atall.

At the regular meeting of the Society held the 21st of July, a committee of five was appointed to draw up a letter containing the above resolutions and also to give some data concerning this important matter and to forward them to all medical societies and journals. We can only say (what our Society has often said before) if this great event be brought about that it will give employment to hundreds of competent physicians, open new paths to the younger members of the profession and prove of great practical usefulness and benefit to the traveling public.

On the steamboats between Fall River, Mass., and New York City there are sometimes as many as a thousand passengers on the boat. Although the trip lasts, as a rule, only nine hours, still there are times when the boats are delayed for hours and it seems that it would be more in keeping with the humanity of the times to have a physician on the boat than to have the expense of canary birds and brass bands and that the money would be much better expended if such were the case. All the steamboats on the Sound, on the Great Lakes, on the long rivers where passengers are of ten for days without medical aid, practice the same economy. Our seagoing steamers running South, as a rule have no physician on board. Some amploy the device of employing the purser as surgeon and when he is pressed, owing to his numerous duties, appoint at times a man who is not any more qualified than the purser to act as a surgeon's assistant. Such steamers as those running from Philadelphia to Portland carry often thirty or forty passengers and a crew of twenty or more and being often out three days should have a physician on board. A passenger on one of the lines running South was obliged to act for the company, as a man had a severe injury and could not be put ashore for three days. The passenger was, fortunately, a surgeon. Again, it is very common on all the steamboats to rely upon traveling physicians to care for sick seamen and passengers. They receive no compensation for their services and are not even returned their passage money. Such conduct is inexcusable besides being a great wrong to the public. Invalid physieians, traveling for their health, have been called up to attend to cases and have suffered greatly in consequence of being disturbed of their night's rest. Cases of childbirth on steamers are not infrequent, and the chairman of this committee had a case of childbirth and was up all night, and on another occasion passed a whole afternoon and night with a patient (one of the waiters) who was suffering from a nearly fatal attack of edema of the glottis. In neither case was any remuneration given nor was the passage money returned. Another member of this committee has often had to perform duties not only of a medical character, but those of a surgeon. The profession is injured in this way, and it is absurd as well as injurious to the profession to have pursers act as surgeons or surgeons perform duties of a clerkly character, and none of which belong to the duties of a shin's surgeon.

We, therefore, protest against the existence of this abuse any longer, and we call upon our medical brothers throughout the land to aid us in any and all ways to abolish this abuse, to 